\title{
sciendo SIMULATION OF THE PROCESS OF METAL HARDNESS MEASUREMENT BY THE ROCKWELL METHOD
}

DOI 10.2478/ntpe-2018-0081

\author{
Prof. dr hab. inż. Stefan Berczyński \\ Dr inż. Daniel Grochała \\ West Pomeranian University of Technology, Poland \\ Dr inż. Zenon Grządziel \\ Maritime University of Szczecin, Poland
}

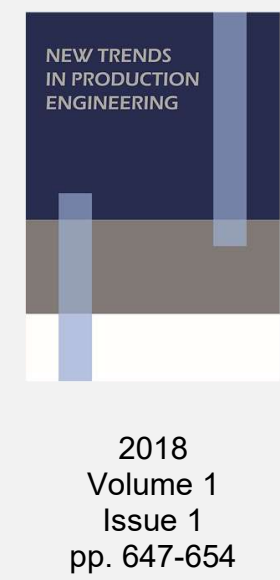

\begin{abstract}
The article presents a simulation of metal hardness determination by the Rockwell method. The authors describe a physical model of an indenter and the examined sample built by means of the Nastran FX 2010 program using the finite elements method. The modelling included subsequent stages of indenter loads that follow the procedure used in the method. The verifying calculations were made for the results of $\mathrm{C} 45$ steel hardness of approx. $20 \mathrm{HRC}$. Two methods of hardness measurements were analyzed. A diamond cone was used as an indenting tool in one method, a steel ball in the other. As a result of calculations, spatial maps of elastic and plastic strains and stresses were obtained throughout the process. The hardness results obtained from computer simulations and those from experiments involving $\mathrm{C} 45$ steel are similar.
\end{abstract}

Keywords: metal hardness, Rockwell method, finite elements method, Nastran FX 2010, elastic strains

\section{INTRODUCTION}

Technical secondary and higher education schools run lab classes in metal hardness measurements by static methods (IPNT; Low, 2000; Konowalski, 2005; WAT). Hardness measurements usually take place in laboratory rooms on dedicated hardness testers. Miniature indenters used in the Rockwell method create miniature indentations visible only under a magnifying glass or a microscope. Modern computer programs based on the finite elements method allow modelling subsequent stages of the indenter pressing process in the Rockwell method and exact imaging on a computer screen of both elastic and plastic strains and stresses (Zhang et al., 2018). The simulations presented in the article may enrich the lab activities by illustrating the processes taking place during the pressing of an indenter into the tested specimen. The principles of Rockwell method hardness measurement are regulated by the standard (PKN, 2016). The indenter may be made in the form of a steel ball (scale B, T, F) or a $120^{\circ}$ diamond cone with a radius of roundness $0.2 \mathrm{~mm}$ for the scale $\mathrm{C}, \mathrm{A}$ and $\mathrm{N}$. This article deals with computer simulation of the hardness measurement process using a diamond cone (determination of HRC hardness) and a steel ball with a diameter $\phi=1.5875 \mathrm{~mm}$ (determination of HRB hardness).

\section{MEASUREMENT OF METAL HARDNESS BY THE ROCKWELL METHOD USING A DIAMOND CONE}

Measurement of metal hardness by this method consists of three stages:

1. In the first stage the indenter is pressed into the specimen with a preliminary minor load $F_{0}=98.1 \mathrm{~N}(10 \mathrm{kG})$. The indenter then penetrates the sample to a depth of $h_{0}$ (Fig. 1).

2. The second stage consists in pressing the indenter with a major load $F_{\max }=F_{0}+F_{g}=98.1$ $+1373.4=1471.5 \mathrm{~N}(150 \mathrm{kG})$. The indenter is loaded with a force $F_{g}=1373.4 \mathrm{~N}(140 \mathrm{kG})$ in addition to the first preliminary load. Then the indenter penetrates the specimen to a depth $h_{g}$. 
3. In the third step the indenter load is $F_{0}=98.1 \mathrm{~N}(10 \mathrm{kG})$. In this stage the additional major load $F_{g}=1373.4 \mathrm{~N}$ is removed. The indenter slightly rises and stops at a depth $h_{k}$ settled in that final stage.

The diagram of metal hardness measurement using a diamond cone is shown in Figure 1.

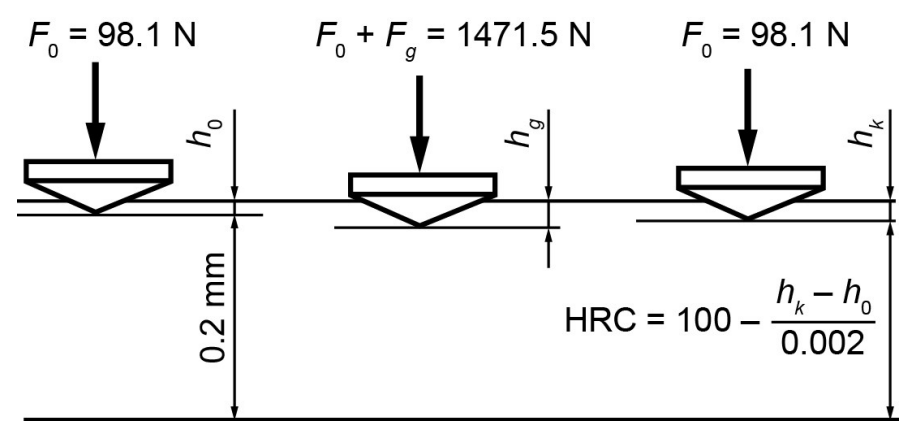

Fig. 1. The diagram of metal hardness measurement by the Rockwell method using a diamond cone indenter with a 120 angle and roundness radius of $0.2 \mathrm{~mm}$. $F_{0}$, $F_{g}$ - preliminary and major loads, $h_{0}, h_{g}, h_{k}$ are respective depths of indentations, HRC hardness in relative units with $0.002 \mathrm{~mm}$ graduation

The measure of hardness in this method is a HRC depth expressed in dimensionless graduation:

$$
\mathrm{HRC}=100-\frac{h_{k}-h_{0}}{0.002}
$$

where: $h_{0}$ is an initial depth obtained in the first stage (indenter is under preliminary load $F_{0}$ ), $h_{k}$ is the final depth obtained in the third stage (under the minor preliminary load $F_{0}$, but after removing the major load $F_{g}$ ).

\section{A computer model of metal hardness measurement by the Rockwell method using a diamond cone (HRC scale)}

Due to the axial symmetry of the system: pressing force - indenter - tested sample - support conditions and in order to reduce the computing time and consequent lower computer memory demand, we have decided to examine a sector of the indenter and metal specimen obtained by turning their axial half-section by $1^{\circ}$, as shown in Fig. 2:

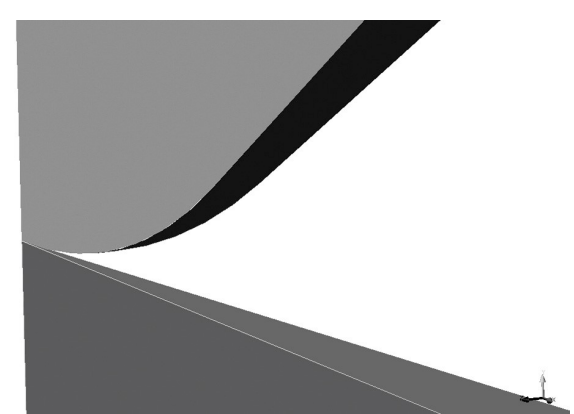

Fig. 2. The examined sector of the indenter and metal specimen obtained by rotating the axial half-section by $1^{\circ}$ angle

The ultimate division into finite elements of the indenter-tested specimen system, obtained from numerous previous simulation tests, is shown in Fig. 3.

The model consists of 2692 nodes and 1300 solids. The metal specimen has a shape of a cylinder with a diameter of $10 \mathrm{~mm}$ and $5 \mathrm{~mm}$ thickness, is made of steel C45 with the plastic limit $R_{e}=700 \mathrm{MPa}$ (Haimann, 1974). Due to the need for modeling permanent plastic deformations the model of steel sample material used was elastic-plastic one with linear strengthening. Calculations made use of non-linear static analysis provided by the Nastran FX 2010 program. The diamond indenter, due to negligible elastic deformations, was simplified to a rigid external dish and modelled by flat elements. This made it possible to use only one rigid 
element replacing the whole indenter. In accordance with the principles of the method, three stages of pressing force applied on the indenter were modelled (Fig. 4):

1. Preliminary minor load $F_{0}=98.1 \mathrm{~N}(10 \mathrm{kG})$.

2. Major load $F_{\max }=1471.5 \mathrm{~N}(150 \mathrm{kG})$, a total of the preliminary load $F_{0}=98.1 \mathrm{~N}$ increased by the major load $F_{g}=1373.4 \mathrm{~N}(140 \mathrm{kG}), F_{\max }=F_{0}+F_{g}=98.1+1373.4=1471.5 \mathrm{~N}(150$ $k G)$.

3. Minor preliminary load $F_{0}=98.1 \mathrm{~N}(10 \mathrm{kG})$. Removal of the major load $F_{g}=1373.4 \mathrm{~N}(140$ $k G)$.

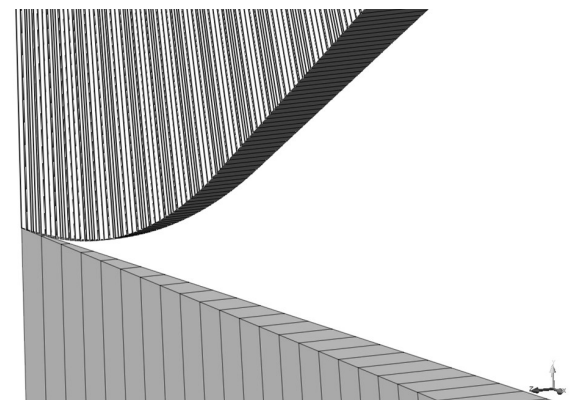

Fig 3. The division into finite elements of the system: indenter - test sample

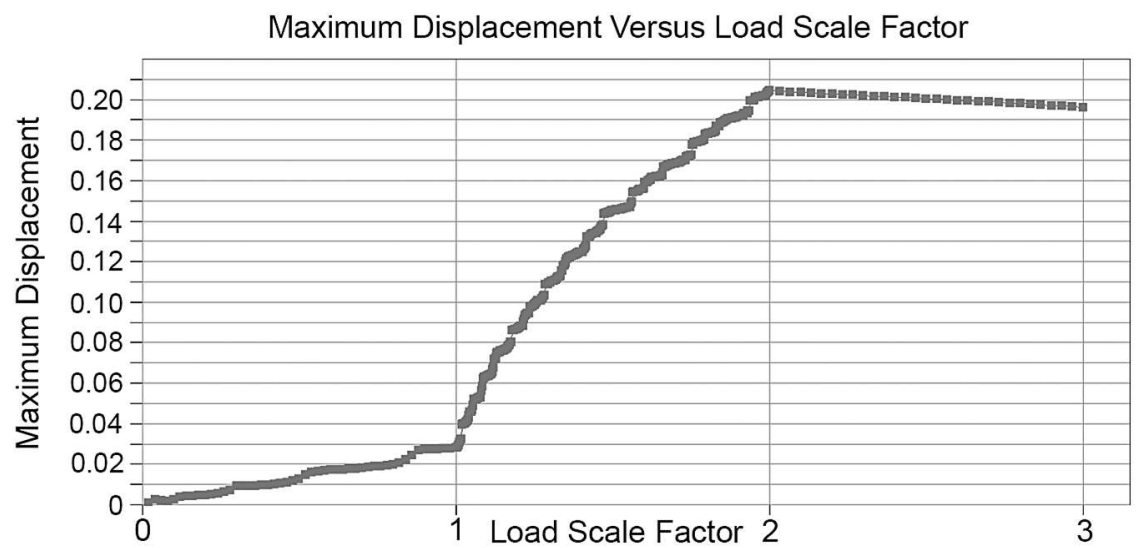

Fig. 4. The curve of maximum deformations in a metal sample caused by pressing a diamond cone in three stages as a function of steps of solutions by the module of non-linear static, obtained in the iterations toward the solution

As a result of computer calculations we get strains, stresses, responses and other quantities. To determine hardness by the Rockwell method we have to know vertical deformations because they occur in final equations for hardness (Formula 2). Figures 5-7 show the results of calculations of those vertical deformations for the three stages of indenter pressing.

Hardness of the tested steel by this method is determined based on the formula:

$$
\mathrm{HRC}=100-\frac{h_{k}-h_{0}}{0.002}=100-\frac{0.1904-0.02937}{0.002}=19.51
$$

where:

$h_{0}$ is an initial depth read from Fig. 4 (indenter is under preliminary load $F_{0}$ ), $h_{0}=0.02937 \mathrm{~mm}$,

$h_{k}$ is the final depth readout from Fig. 5 (also under preliminary load $F_{0}$, but after removing the major load $F_{g}$ ), $h_{k}=0.1904 \mathrm{~mm}$.

Hardness $19.51 \mathrm{HRC}$ means that it is very soft steel. For hardness less than $20 \mathrm{HRC}$ the method should not be used, and replaced by HRB, that is a steel ball indenter with lower major load $F_{g}$. Further in the article we discuss the measurement of hardness using a steel ball. 


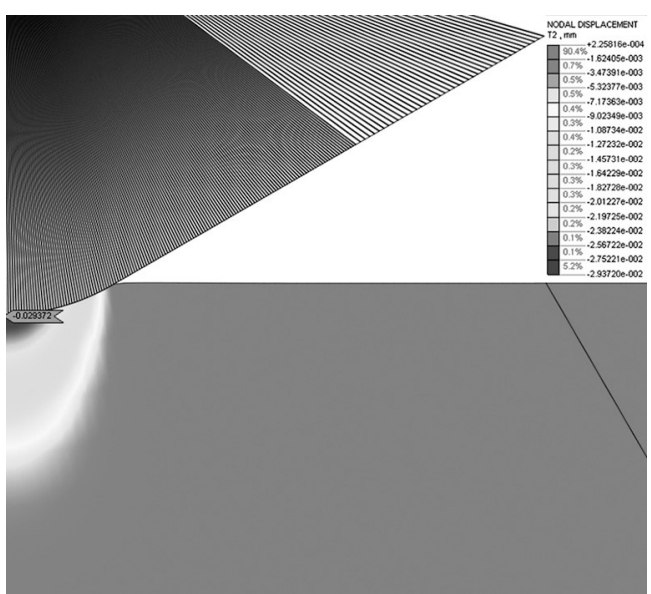

Fig. 5. Vertical deformations under preliminary load $F_{0}=98.1 \mathrm{~N}(10 \mathrm{kG})$

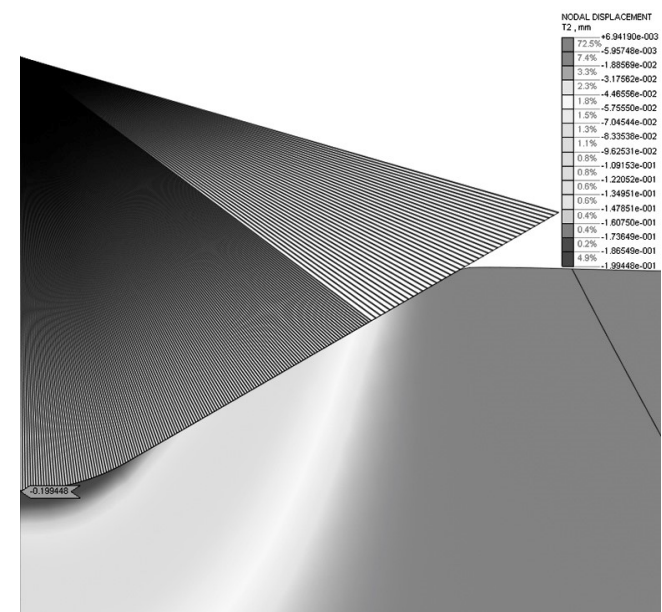

Fig. 6. Vertical deformations under major load $F_{0}+F_{g}=98.1+1373.4=1471.5 \mathrm{~N}$ (150 kG)

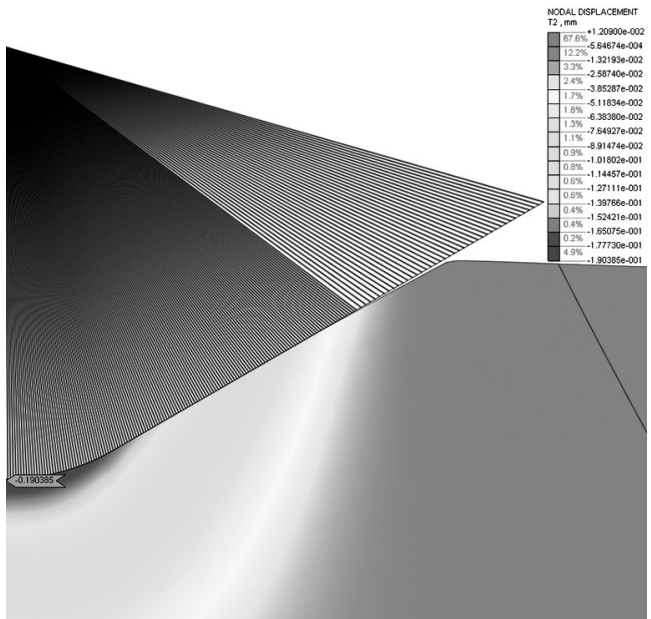

Fig. 7. Vertical deformations after returning to preliminary load $F_{0}=98.1 \mathrm{~N}(10 \mathrm{kG})$. Removal of the major load $F_{g}=1373.4$ N (140 kG)

METAL HARDNESS MEASUREMENT BY THE ROCKWELL METHOD USING A STEEL BALL

The diagram of metal hardness measurement by the Rockwell method using a steel ball with a diameter of $1.5875 \mathrm{~mm}$ does not principally differ from that using a diamond cone, previously shown in Figure 1 (Fig. 8).

The preliminary load is the same $F_{0}=98.1 \mathrm{~N}$, while the maximum load applied is lower $F_{\max }=F_{0}+F_{g}=98.1+882.9=981 \mathrm{~N}(100 \mathrm{kG})$. 


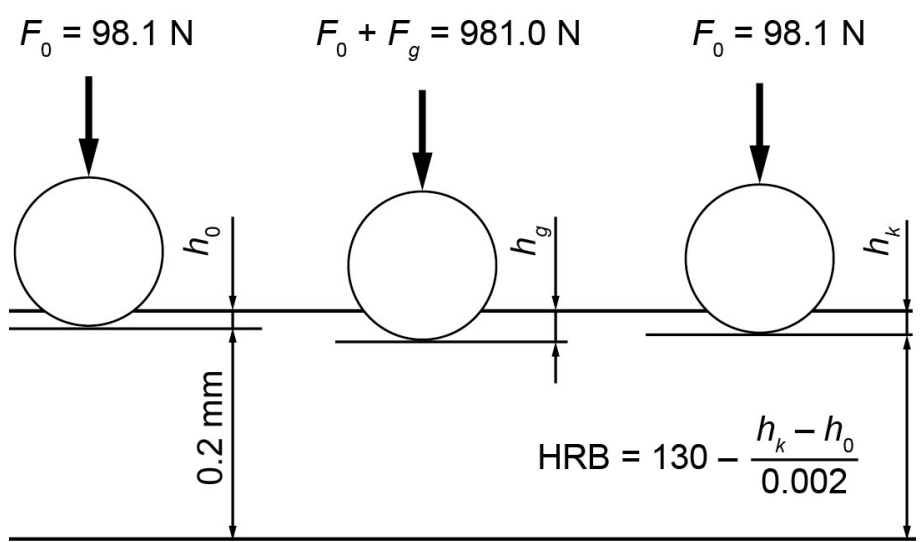

Fig. 8. The diagram of metal hardness measurement by the Rockwell method using a steel ball indenter with a diameter $1.5875 \mathrm{~mm}$ (HRB scale). $F_{0}, F_{g}$ - preliminary and major loads, $h_{0}, h_{g}, h_{k}$ - respective depths of indentations,

HRB hardness expressed in relative units with $0.002 \mathrm{~mm}$ graduation

A computer model of hardness measurement by the Rockwell method using a steel ball with a diameter $1.5875 \mathrm{~mm}$ (HRB scale)

A computer model of a sample metal is exactly the same as in Fig. 3, while the indenter is modelled as a sector of a rigid spherical dish.

Figures 10-12 show the results of computer calculations of vertical deformations for three stages of pressing a steel ball indenter (Fig. 9).

Hardness of the tested steel by this method is determined from this formula:

$$
\mathrm{HRB}=130-\frac{h_{k}-h_{0}}{0.002}=130-\frac{0.06721-0.01047}{0.002}=130-28.37=101.6
$$

where:

$h_{0}$ is an initial depth read from Fig. 10 (indenter is under preliminary load $F_{0}$ ), $h_{0}=0.01047 \mathrm{~mm}$,

$h_{k}$ is the final depth read from Fig. 12 (also under preliminary load $F_{0}$, but after removing the major load $F_{g}$ ),

$h_{k}=0.06721 \mathrm{~mm}$.

The obtained hardness was 101.6 HRB.

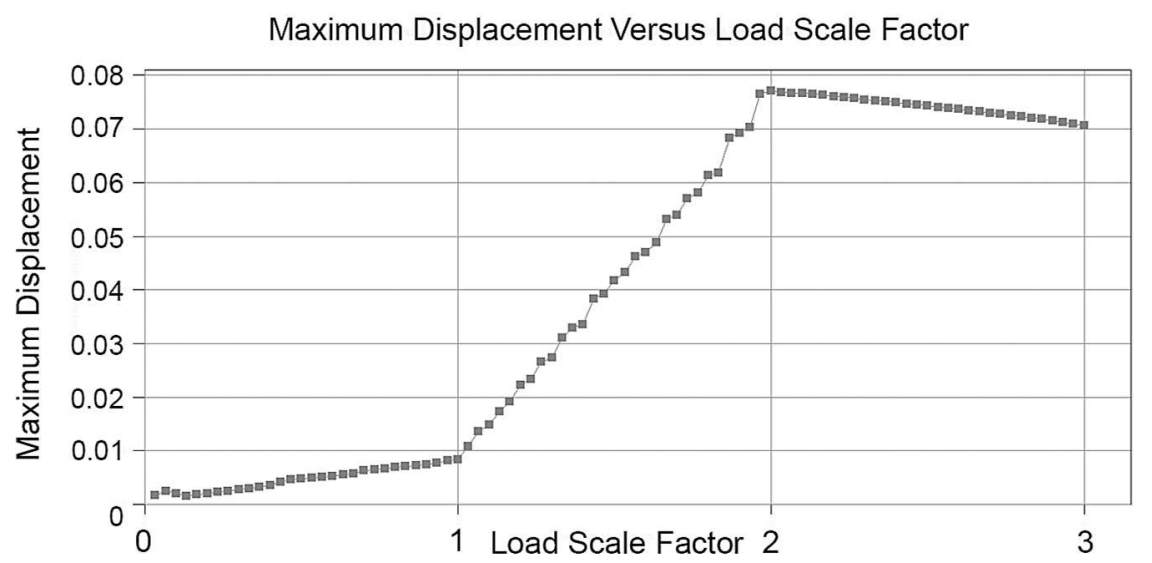

Fig. 9. The curve of maximum deformations in a metal sample caused by pressing a steel ball in three stages as a function of steps of solutions by the module of non-linear static, obtained in the iterations toward the solution 


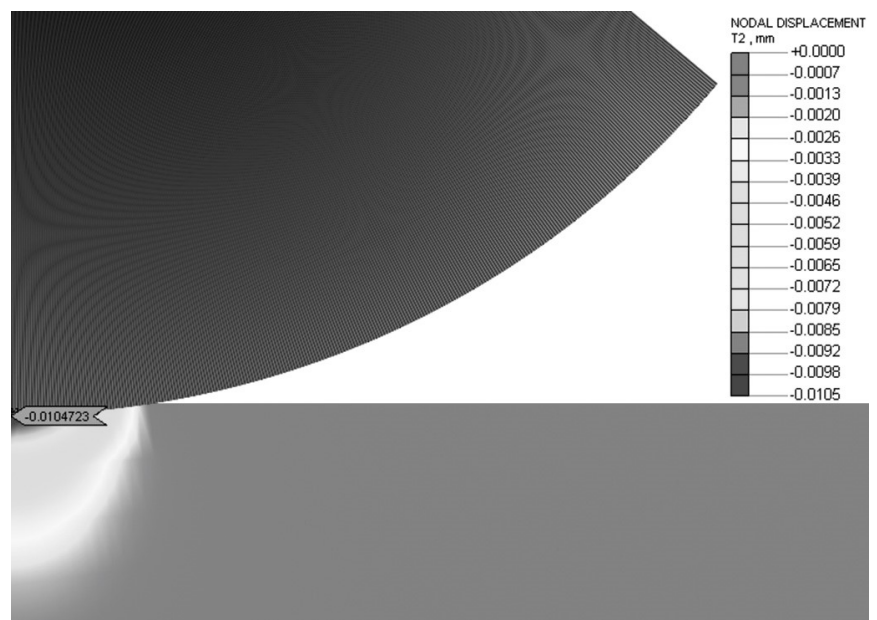

Fig. 10. Vertical deformations under preliminary load $F_{0}=98.1 \mathrm{~N}(10 \mathrm{kG})$; a steel ball indenter

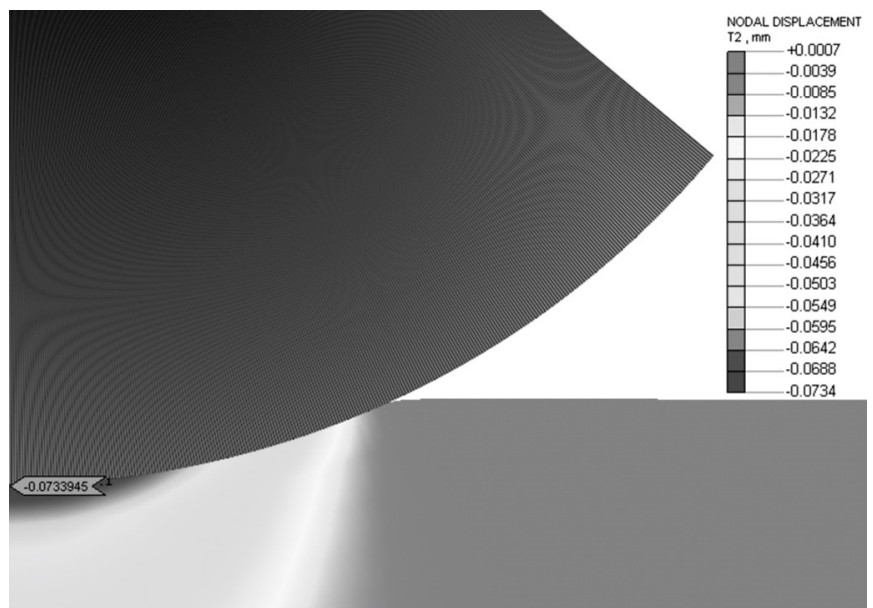

Fig. 11. Vertical deformations under major load $F_{0}+F_{g}=98.1+882.9=981 \mathrm{~N}(100 \mathrm{kG})$; a steel ball indenter

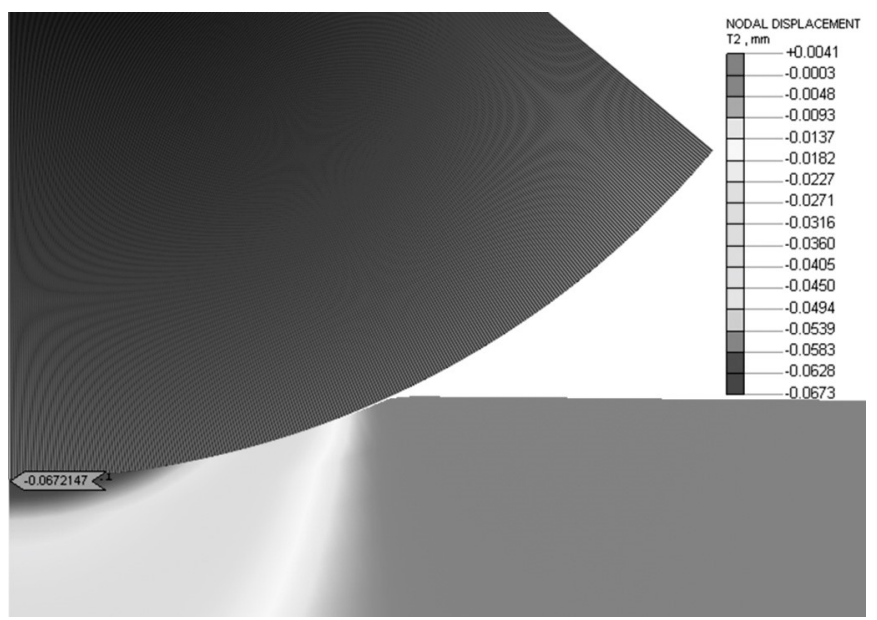

Fig. 12. Vertical deformations after returning to initial load $F_{0}=98.1 \mathrm{~N}(10 \mathrm{kG})$. Major load removed $F_{g}=882.9 \mathrm{~N}(90 \mathrm{kG})$; a steel ball indenter

\section{SUMMARY}

To compare the HRC hardness from experiments and simulations for various yield points Re for C45 steel we used the diagram from publications (Haimann, 1974; Politechnika Gdańska), as presented in Fig. 13. 


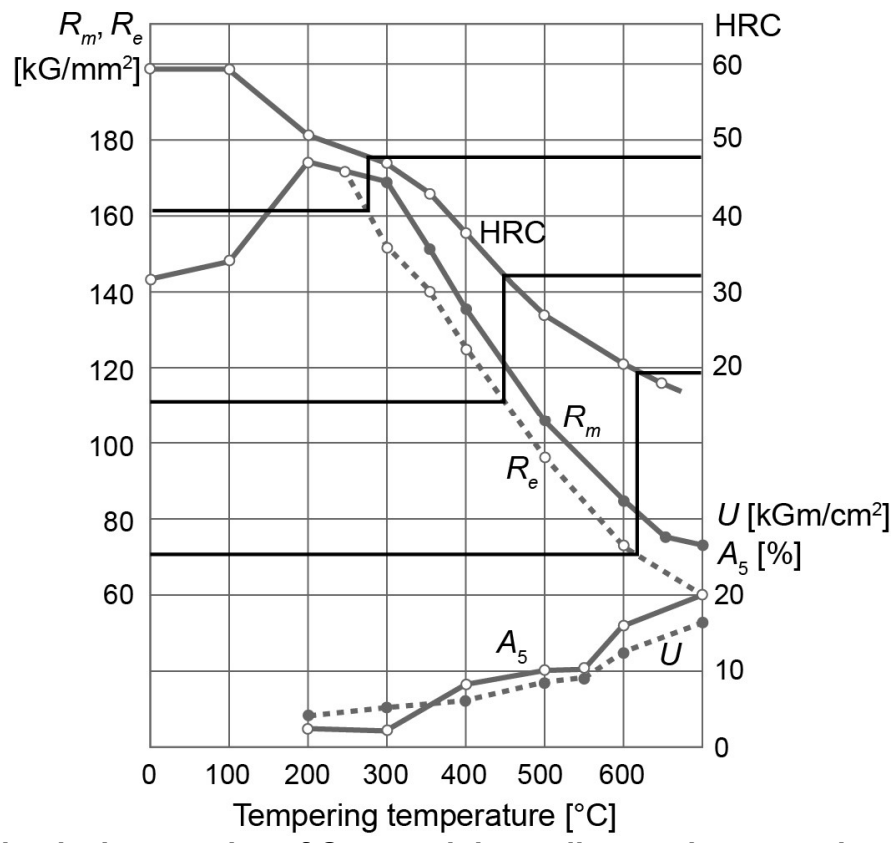

Fig. 13. Mechanical properties of $\mathrm{C} 45$ steel depending on the tempering temperature (hardening at $840^{\circ} \mathrm{C}$, water, sample diameter $10 \mathrm{~mm}$ ) (on the basis of Haimann, 1974)

Table 1 presents experimental data derived from a graph in Figure 13 and simulated data obtained by the computing for three representative values of yield point: $R_{e}=700,1100,1600$ $\mathrm{MPa}$. For the yield point $R_{e}=700 \mathrm{MPa}$ the obtained hardness was below $20 \mathrm{HRC}$ and for that yield point value additional simulation calculations were made as per the HRB method. To compare the obtained simulation value of HRB hardness we used HRB-HRC conversion tables (Steel Express). According to this source (96-97) HRB corresponds to (19-20) HRC. Simulation results of $\mathrm{C} 45$ steel sample hardness are contained in Table 1.

Table 1.

Hardness of C45 steel: experimental HRC from Fig. 13, simulated by HRC method and simulated by HRB method converted to HRC hardness.

\begin{tabular}{|c|c|c|c|c|c|c|}
\hline & \multirow{2}{*}{$\begin{array}{c}\text { Yield point } \\
R_{e}[\mathrm{MPa}] \\
\text { as per } \\
\text { Fig. } 13 \\
\end{array}$} & \multirow{2}{*}{$\begin{array}{l}\text { The strengthening/ } \\
\text { fixing module } \\
\text { [MPa] }\end{array}$} & \multicolumn{2}{|c|}{ HRC hardness } & \multirow{2}{*}{$\begin{array}{c}\begin{array}{c}\text { HRB } \\
\text { hardness }\end{array} \\
\text { Simulated }\end{array}$} & \multirow{2}{*}{$\begin{array}{c}\text { HRC } \\
\text { hardness } \\
\text { Converted }\end{array}$} \\
\hline & & & $\begin{array}{l}\text { Experi- } \\
\text { mental }\end{array}$ & Simulated & & \\
\hline \multirow{3}{*}{$\begin{array}{l}\text { Steel } \\
\text { C45 }\end{array}$} & 700 & 6000 & 19 (Fig. 13) & $\begin{array}{c}19.51 \\
\text { formula (2) }\end{array}$ & $\begin{array}{c}101.6 \\
\text { formula (3) } \\
97^{* *}\end{array}$ & 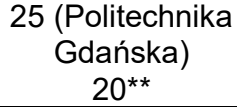 \\
\hline & 1100 & 7000 & 33 (Fig. 13) & $32.97\left(^{*}\right)$ & & \\
\hline & 1600 & 14500 & 47 (Fig. 13) & $46.29\left(^{*}\right)$ & & \\
\hline
\end{tabular}

* the values obtained from the computer simulation, but not included in the study;

${ }^{* *}$ reference values.

For $\mathrm{C} 45$ steel, subject of this study, the relation between HRC hardness and yield point $\mathrm{Re}$ is expressed by this formula (Yang et al., 2008):

$$
\mathrm{HRC} \approx 0.03 R_{e}
$$

\section{REFERENCES}

Haimann, R. (1974). Metaloznawstwo. Wrocław: Politechnika Wrocławska.

IPNT. Twardość metali. [online] Available at:
https://www.am.szczecin.pl/userfiles/File/laboratoria/wm/IPNT/Twardosc_metali.pdf [Accessed 10 Apr. 2018].

Karakasidis, T.E., Georgiou, D.N. and Nieto, J.J. (2012). Fuzzy regression analysis: An application on tensile strength of materials and hardness scales. Journal of Intelligent \& Fuzzy Systems, 23(5), pp. 177-186. 
Konowalski, K. (2005). Pomiary twardości metali. [online] Available at: http://kmpkm.zut.edu.pl/pub/Ogloszenia/Konowalski\%20Konrad/Skrypty/Pomiary\%20twar dosci\%20metali.pdf [Accessed 10 Apr. 2018].

Low, S.R. (2000). Rockwell Hardness Measurement of Metallic Materials. Washington: National Institute of Standards and Technology.

PKN (2016) PN-EN ISO 6508-1:2016-10 EN, Metale - Pomiar twardości sposobem Rockwella - Część 1: Metoda badań.

Politechnika Gdańska. Podstawy obróbki cieplnej stopów żelaza. Hartowanie i odpuszczanie. [online] Available

at: http://www.im.mif.pg.gda.pl/download/materialy_dydaktyczne/PIM_15_hartowanie_odpus zczanie.pdf [Accessed 10 Apr. 2018].

Steel Express. Steel Hardness Conversion Table. [online] Available at: http://www.steelexpress.co.uk/steel-hardness-conversion.html [Accessed 10 Apr. 2018].

WAT. Pomiary twardości i mikrotwardości. [online] Available at: (http://www.wtc.wat.edu.pl/images/dydaktyka/katedra/jozwiak/pomiary_twardosci.pdf [Accessed 10 Apr. 2018].

Yang, R., Zhang, T.H., Jiang, P. and Bai, Y.L. (2008). Experimental verification and theoretical analysis of the relationships between hardness, elastic modulus, and the work of indentation. Applied Physics Letters, 92(23), pp. 231906.

Zhang, T., Jiang, F., Lan, Y. and Xu, X. (2018). FEM Modeling of the Relationship between the High-Temperature Hardness and High-Temperature, Quasi-Static Compression Experiment. Materials, 11(1), pp. 34.

Date of submission of the article to the Editor: 02/2018

Date of acceptance of the article by the Editor: 05/2018 